Vol. 4, Special Issue 2, January 2017

\title{
GSM and RFID Based Library Book Availability and Location Finder System
}

\author{
Miss. Salunkhe Monali ${ }^{1}$, Prof. Gaikwad S.A. ${ }^{2}$ \\ Student- Bachelor of Engineering, Electronics \& Telecommunication Engineering Department, Dr Daulatrao Aher \\ College of Engineering, Karad, Maharashtra, India. ${ }^{1}$ \\ Assistant professor, Electronics \& Telecommunication Engineering Department, Dr. Daulatrao Aher College of \\ Engineering, Karad, Maharashtra, India. ${ }^{2}$
}

\begin{abstract}
GSM \& RFID Library book availability \& location finder system is very essential for digital libraries. RFID system is now very important because it play a very essential role to reduce human efforts. For find the location of each \& every book we need to implement RFID tag. User sends the message to GSM modem. This message is accept by Arduino board \& pass it to RFID Reader through level converter. RFID Reader pass that code to RFID Card. RFID Card reads that message \& message is transfer to RFID Reader, then Arduino board send that message to Motor driver then Motor starts rotating and if book is available then motor will be stop.
\end{abstract}

Keywords: GSM- Global System for Mobile, RFID- Radio Frequency Identification, Arduino Mega 2560, Arduino software, LCD- Liquid Crystal Display, RS-232-standerd for serial communication.

\section{INTRODUCTION}

Libraries are the source of knowledge. In libraries a thousands of books are available so the process of searching any book is very time consuming.[1]

To reduce this efforts of users we are introducing our project. So that we can easily find out book availability and its location. This project is very essential in digital library. When RFIDljy tags are embedded into book then its not visible for detection.[2]

We use passive RFID tags and the range of tag is $10 \mathrm{~cm}$ only.There is problem of battery charging and discharging. In this library system we use arduino board. The arduino board 2560 is depends on ATmega2560.[3]

It is one type of microcontroller. Arduino operates on TTL series.[1]GSM modem works on the wireless network. A GSM modem is a external unit they require sim card.[4]

GSM modem is connected to pc through a USB cable. GSM operates on RS232.[5].

This library system capable to reducing the human efforts. This proposed system is completely based on GSM and RFID technology. For simplification we use ARDUINO MEGA 2560.[7]

We can interface PC here. Arduino Mega 2560 consists of 2 serial ports. The RFID technology is useful for fast issuing, returning and reissuing of the books.[10]

\section{BLOCK DIAGRAM}

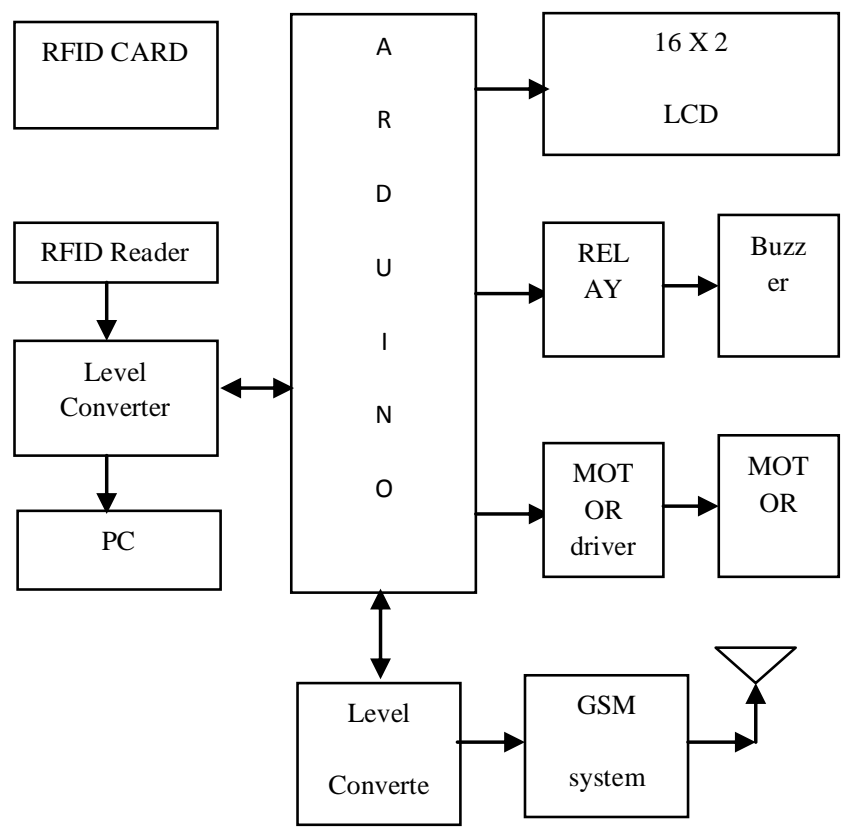

fig.1 Block diagram

\section{HARDWARE DETAILS}

\section{A. RFID}

RFID- Radio Frequency Identification.

RFID is a small electronic device that consists of an small chip and antenna. The chip carries 2,000 bytes of data.[4] The RFID device scanned to retrieve the identification information.[3] 
IARJSET

International Advanced Research Journal in Science, Engineering and Technology

National Conference on Emerging trends in Electronics \& Telecommunication Engineering (NCETETE 2017)

AGTI's Dr. Daulatrao Aher College Engineering, Vidyanagar Extension, Karad

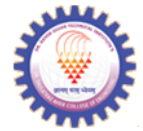

Vol. 4, Special Issue 2, January 2017

RFID Card

RFID tag consists of a microchip which identifies 4 the information. An antenna is a wireless reader.[3]

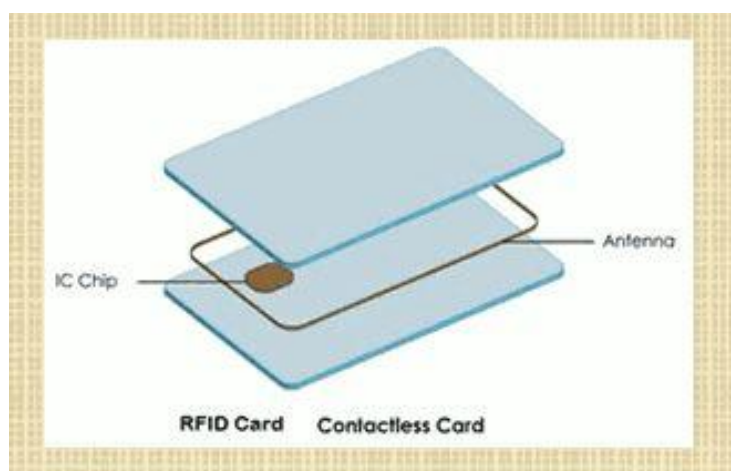

fig.2 RFID CARD

RFID chip contain a serialized identifier, or license plate number, that uniquely identifies that item, similar to the way many bar codes are used now a day's .[6]

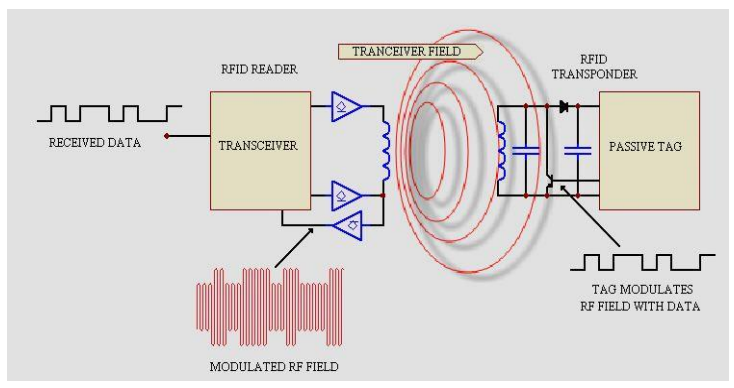

fig.3Working in RFID chip

\section{B. ARDUINO MEGA2560}

The Arduino mega 2560 is very important for more complex projects. The Arduino Mega 2560 is based on the ATmega2560[3].Board consists of a 54 digital input/ output pins. In that 14 pins are used as a PWM outputs, 16 are analog inputs, 4 are UARTs that means hardware serial ports, a $16 \mathrm{MHZ}$ crystal oscillator, a USB connection ,a power jack, an ICSP header, and a reset button.[4]

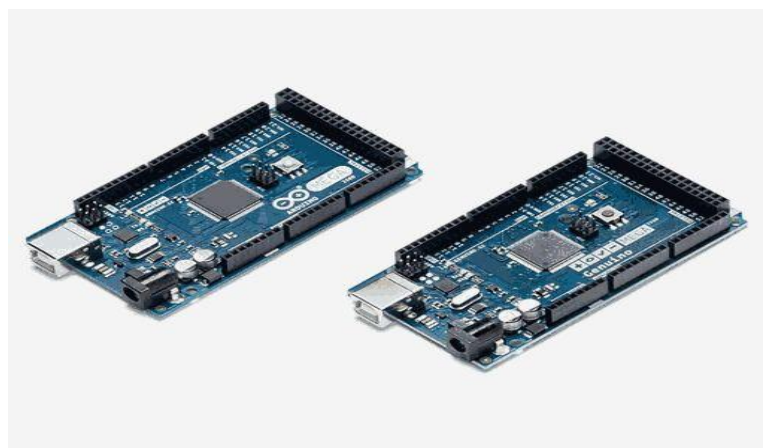

Fig.4 ARDUINO MEGA 2560

Features

1. Operating Voltage $5 \mathrm{~V}$

2. Input Voltage (recommended) $7-12 \mathrm{~V}$
3. In put Voltage (limits) 6-20V

Digital I/O Pins 54 (of which 14 provide PWM output)

5. Analog Input Pins 16

6. DC Current per I/O Pin $40 \mathrm{~mA}$

7. Flash Memory $256 \mathrm{~KB}$ of which $8 \mathrm{~KB}$ used by boot loader.

\section{GSM SYSTEM}

GSM: Global System for Mobile communication.

GSM is a wireless modem that works with a GSM wireless network. Dial up modem send \& receives data through radio waves. In order to operate, GSM modem requires a SIM card from a wireless carrier.[4] A GSM modem can be a PCMCIA Card. GSM Modem can be controlled by AT Commands of PC.

\section{GSM ATMEGA INTERFACE}

GSM is used for call management system in telecommunication field.

Here we shows the connection in between GSM \& Atmega 232. GSM is used for call management system in telecommunication field. It is useful in wireless communication such as mobile communication. GSM frequency rane is $900 / 1800 \mathrm{MHZ}$.

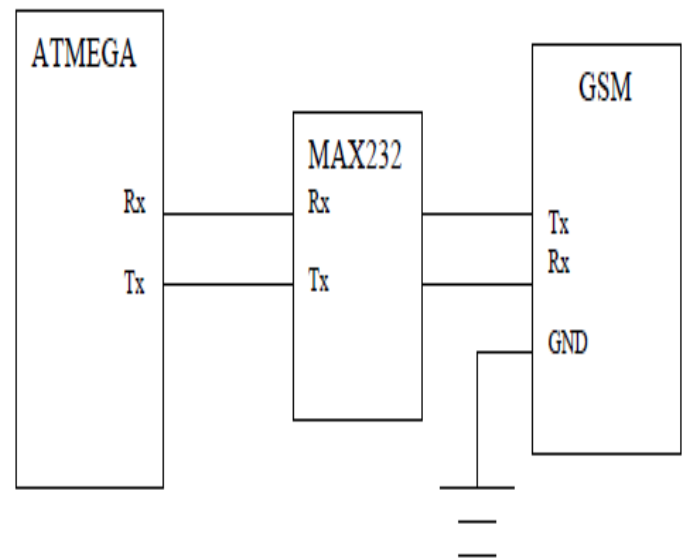

fig 5. GSM is connected to Atmega via MAX 232.

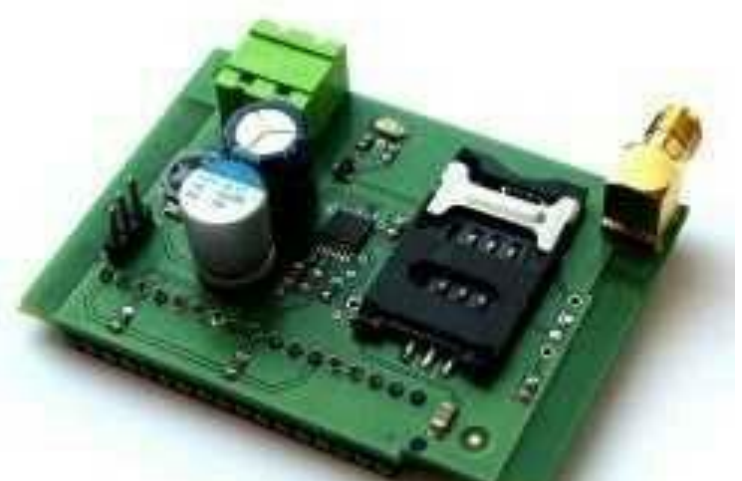

fig.6 Interfacing of GSM modem with ATmega Microcontroller. 
IARJSET

Vol. 4, Special Issue 2, January 2017

\section{WORKING}

1. This project is completely based on GSM and RFID module. First we send the message to GSM modem. GSM is operates on the RS232 \& Arduino is operates on the TTL series. So for interface this two devices we need ICMAX232 as a level converter.

2. That message is accepted by the microcontroller of Arduino Mega 2560.

3. Arduino sends that message to RFID Reader the through level converter.

4. RFID reader pass the signal towards RFID Card. Which accepts that signal \& read that message in which we send the code of book which we want.

5. This code is again send Arduino board and then it pass to Motor driver .Motor starts rotating.

6. If our book is available then motor will be stop their \& LCD screen displays that book is available.

7. After that relay will be on \& buzzer will be start. Then we can find the actual book location.

\section{SOFTWARE DETAILS}

\section{A. Arduino software}

IDE- Integrated Development Environment. Arduino software (IDE) is a open source platform to write easy code and upload it to the board. Windows, Mac OS $\mathrm{X}$, and Linux on this types of operating system we can use arduino software. Arduino software has easy installation process. The arduino board can either be preassembled or we can assemble data manually. [4]

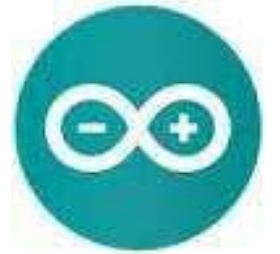

fig.7 symbol of Arduino software.

\section{B. PROTUS 8 PROFESSIONAL}

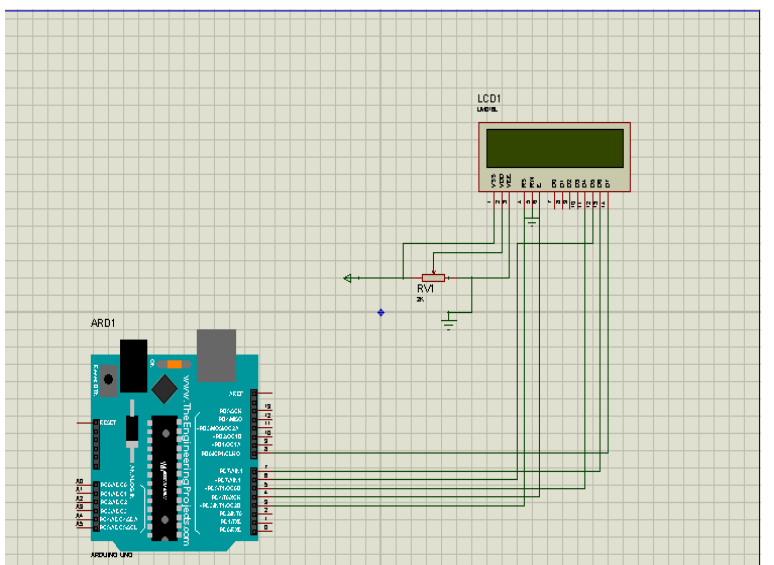

fig.8. Interfacing of LCD and Arduino mega 2560 on protus 8 professional software.

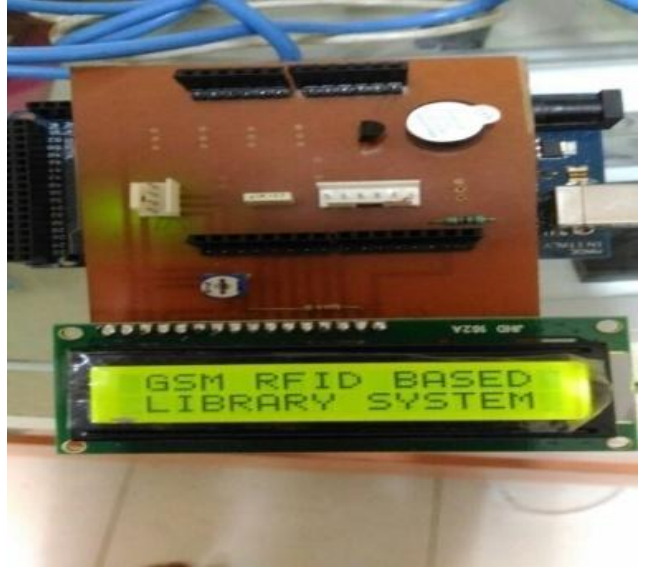

fig.9. Display project name on LCD

\section{APLLICATIONS}

This system is applicable in library system to identify the documents.

2. In today's libraries are digitalized. So this system is very applicable to find electronic devices such as DVD'S, CD'S and so on.

3. This technology offered by the library to the user will be more effective and efficient.l

4 libraries.

This library system is applicable for most big

\section{ADVANTAGES}

1. This system is time consuming.

2. Easy for implimentation.

3. Low cost Method.

4. We can interface PC here.

5. The readers wil installed at the entry and exit doors of the library.

\section{CONCLUSION}

The proposed system is very efficient in terms of technology. This system is easy to use and time saving and efficient to find book in library. The cost of RFID based library system is high but the cost of maintenance and time consumption of these libraries are reduced.

\section{REFERENCES}

1. Srujana, B. R. Rama Murthy, "Development of RFID Based Management system MATLAB C.”, page no.234.

2. Hideaki Araki, Hirohide Haga, and Shigeo Kaneda, "Automatic Updating of a Book Storage Database".

3. Shamsudin,T.M.W. Salami, M.J.E. Mortono,W, "RFID Based intelligent Books Shelving System".

4. Akhil chowdhari, sankalp Joshi, Akshay Bembalkar, Nainesh Marathe, L.J. Sankpal ,"Book Tracking Application in Android for Library using GPS", International Journal of innovative research in computer \&communication Enginnering Vol. 1, Issue 1,march 2013.

5. Digvijay H. Bhoir, Swapnil D. Vishe, Prasad D. Sase, Jitesh T. Patil, "Library Mnagement \& Enquiry System using GSM", 
International Journal on recent \& Innovative Trends in computer \&communication Vol. 4, Issue 4.

6. Karen Coyle, "Management of RFID in libraries", Preprint version of article published in the journal of academic library Librarianship, vol. 31, n.5,pp.486-489.

7. S. Vimalraj, S. Sameera,"RFID Based Library Management system",International Journal of Innovative Research in advanced Engineering(IJIRAE),ISSN:2349-2163,issue 1,volume 2 (January 2015)

8. Mrunal A. Kausal, Ishwar Jadhav, S. R. Pachpande, kantilal P. Rane, "A paper on RFID in Library Automation", International journal of Advanced Electronics \& Communication System, CSIRNISCAIR ISSN NO: 2277-7318.

9. Moiz S. Ansari, Naveed Ghani Khatri, "Automatic RFID Based Library Management system", Symposium on Information \& computer science (ICS 2011).

10. Priyanka Grover and Anshul Ahuja,"RFID Based Library Management system", International Journal of Advanced Computer science and Applications, Vol. 1, NO. 1, July 2010.

11. Dhanalakshmi M.,Uppala Mahatha, "RFID Based Library Management System." 